\title{
Universal Military Service
}

\section{Richard Becker}

M y great-grandfather came to America from Germany; he came because he did not believe in Germany's program of universal military training. Today, nearly eighty years later, the United States is contemplating a similar program, and its young men are faced with an uncertain and compelling future. I believe, however, that the youth of today face the problem with a different outlook than did the people of my greatgrandfather's day. In my opinion, the young men of America realize that they live in the most ideal country in the world and that it is worth defending. There are, however, varied opinions as to whether or not universal military service is the right way in which to defend it.

It is the opinion of one group that if a "wall of peace" is to be maintained, universal service is the only answer. This the eighteen - twenty year age is the in regard to education, man to serve because at this age he logical time for a young and is just beginning college. The belief completed high school that the system of selective service is unfair to these people selected. On the other hand, there is the to those who are that universal service is not the answer group which feels preventing war. They point particinants in the fact that many of the participants in both world wars had similar programs. This group also believes that nniversal service is war breeding because such a program could hardly be considered a peaceful gesture by suspicious nations.

I feel that both sides of the argument have good points. I believe that the young men of today would be willing to give their time and, if necessary, their lives if they were sure that it would preserve a "wall of peace." Of course, it would be exremely difficult for the average young man to leave his home and his loved ones, but if there were a definite time for him to go, he would be somewhat accustomed to the idea. However, under the present program, one may be called at any time; this, I believe, causes one to live in an atmosphere of uncertainty and worry. I believe that it would be a good plan to enter universal service after finishing high school. Then after one finished his training, he would be free to enter college or take up an occupation with no fear of interruption. There are sound reasons for deferment, but I cannot feel that the major part of them are fair to those who must serve. 
Considering the argument of the opposing group, though, I can readily understand their reasoning. War and preparation for war does not blend with normal, happy living, and it does not encourage peace. However, the world is not in a normal or happy condition at present, and it seems that the only independent countries to strvive will be those countries which are able to defend their rights, beliefs, and privileges. Because of this condition I believe that the young men should, and will, be willing to serve their country. I believe just as firmly, though, that these young men should be given a definite idea as to when they are to serve. In this way they will be able to include, with a greater degree of certainty, universal military service in their life plans.

$$
++\neq+\neq
$$

\section{My Leisure Time}

\section{Joan Ruch}

A fter a busy and strenuous day here in the city, I long to reA treat into a certain quiet woods located on our farm at Frankfort, Indiana. I especially enjoy this place in summer, but to me it is always a "nature wonderland." I first descend the hill where the green prairie begins. The constant buzzing of the grasshoppers and locusts seems to rise and fall with the heat of the warm sun. The green lowlands give no shade to the scattered dandelions and clover plants which seem to bend under the heat's force. I then cross the creek to the woods at the other side. In the cool dense woods violets "peep" cheerfully through the folige at the feet of the great trees. A bird nearby flutters to a higher branch, and the turtles which are sunning themselves slip into the water as I approach. I love to hear the constant rushing of the creek over the old logs and rocks. At the bend of the creek, which is more shallow, I can ustrally see many different kinds of fish. I love to settle myself quietly upon the bank of the creek. Soon the turtles again climb upon the logs, the disturbed bird calmly returns to her nest, and the frogs again contentedly begin their croaking. The confusion and complexity of the "outside world" fade, and I find myself completely relaxed. I love to sit here until evening when the sun disappears behind the hill of the great bank across from me. Often I see an old racoon waddle to the 